\title{
Higher Education and the Enduring Value of Hospitality: Reflections for the 21st Century
}

\author{
Gerardo L. Blanco
}

\section{Introduction}

The 21st century is a perilous time for international collaboration among university actors. Mobility and international exchange have come to a total standstill as the world shelters in place, trying to slow down the course of a pandemic. However, the crisis of hospitality in higher education has been long in the making. Within universities, internationalization has been driven by profits and revenues for decades, while discussions of core values have been cast aside as utopian or idealistic. There are thousands of displaced, imprisoned and exiled academics, and there are millions of university-aged refugees in the world, with only a tiny fraction of them entering universities. Beyond university walls, scepticism toward the other has been brewing, popularizing xenophobic nationalism and construing mobility as a threat that must be curtailed or regulated to new extremes. As some governments have turned to authoritarianism, universities have become targets, and government actions have resulted in significant numbers of displaced and unemployed academics, many of whom look beyond national borders to find spaces where the pursuit of their ideas is less threatening and where they can exercise their intellectual calling. Responding to these needs requires hospitality, which is not unprecedented, but that has become a lower priority among many others such as the constant pressure to move up the rankings or league tables.

It can also be observed that, judging by policies and the attitudes of local students and the general populace, some of the most sought-after countries for international mobility are also among the least hospitable. In the United States, which is the largest recipient of international students, xenophobic incidents against international students have been recorded, and policymakers have singled out international students and visiting scholars from China, the largest sender of students and scholars,

G. L. Blanco $(\varangle)$

Boston College, Chestnut Hill, MA, USA

e-mail: blancoge@bc.edu

(C) The Author(s) 2021 
as potential spies or thieves of intellectual property. These examples illustrate an ongoing crisis of hospitality. This chapter explores the contours of hospitality in the context of higher education and imagines the possibility of universities radically and unconditionally open to hospitality. As the International Association of Universities (IAU) celebrates its seventieth anniversary, revisiting hospitality as an enduring value that guides the work of universities constitutes a timely and necessary task.

\section{Hospitality, Hostility and the Other}

Like UNESCO and the UN, it is possible to situate the origins of the IAU in the historical context of building global institutions after the Second World War. With this background in mind, reminded of the post-war ravages and displacement, it is easy to argue that hospitality is an enduring value of universities and worth of analysis as IAU begins its eight-decade of existence. This is also a momentous task, given that the first two decades of the 21 st century have been marked by climate change, refugee crises and large political shifts in the direction of xenophobic nationalism. As vast portions of the world continue to shelter in place, and as an unprecedented number of borders remain closed in an attempt to slow down the pace of a pandemic, the idea of unconditional hospitality as an enduring university, and therefore universal, value is not only timely but urgent.

In a surprising twist, the word hospitality is etymologically connected not only to host, but also to hostage and hostility (Dufourmantelle and Derrida 2000). This connection may account for the fact that it is not possible to be open to others and other's ideas without incurring in risk or the possibility of conflict. Whether we dub it global, universal or cosmopolitan, the university — as ideal—involves both convergence and conflict of ideas and both are enshrined in the IAU Constitution. However, it appears that universities have moved away from their embrace of vigorous argumentation as societies find solace in the echo chambers of like-minded social media contacts and followers. Heated debate and the frustrating task of welcoming someone else's ideas that one might find wrongheaded or even offensive pales in comparison with the appeal of surrounding oneself, albeit only electronically, by those who are already in agreement, blocking those who might think differently. Perhaps to the same extent that open intellectual antagonism has given way to ideologically segregated spaces on campus, hospitality, too, has receded.

Taking the next step in this chain of words-from hospitality to hostility-we arrive at an unsettling term: hostage. There is no hospitality without the other, and Levinas (1989) goes as far as stating: "I am hostage to the Other" (160). The other, who receives our hospitality, is always foreign - a stranger in Romance languagesand therefore strange (Bauman 2016) to us. This is a central role of universities, which for centuries have promoted cosmopolitan values: to make the others familiar, embracing their foreignness without erasing differences. This is the balancing act of universities: to promote peaceful co-existence without committing the violence of cultural cloning. Even as we commit to specific values, and while all societies 
include a principle of hospitality (Derrida 2005b), this universality does not mean sameness in how the value is manifested across cultural contexts. While welcoming ideas is widely recognized as an academic and intellectual value, we might also remember that ideas are always, at some point, embodied — even written words have authors - and as a result, welcoming new ideas always involves welcoming the other.

\section{Radical or Not at All}

Universities in the 21 st century cannot relinquish their calling to universality, but their global connections must not be subordinated to economic interests, but rather emerge from a deep commitment to enduring values. Just as universities continue to defend their obligation to interrogate and deconstruct (Derrida 2005a), they must remain unconditionally hospitable to ideas, and to those generating them, regardless of how foreign they may appear. Universities also need to remain fundamentally open to those who have been systematically excluded from the benefits afforded by these most enduring and resilient institutions and to those who have been displaced or endangered for exercising their right to think and express their ideas. Just like the slightest interference with academic freedom threatens to invalidate the entire intellectual enterprise of universities, it is necessary to be vigilant that the smallest violation to the principle of hospitality in universities - which can be extended to ideas, individuals and groups_-runs the risk to overturn the role of universities as sanctuaries of knowledge.

It is the duty of those of us, fortunate enough to inhabit within universities, to extend this principle of hospitality to the future. This involves future generations, of course, and as such it is necessary to be committed to sustainability and serving as good stewards of these great institutions, mobilizing them to solve the great challenges that humanity faces. As well, we have an obligation to extend this principle of hospitality to new forms of instruction that may appear foreign-even from a different dimension or from an alternate reality as we have been forced to reimagine our teaching altogether as a result of COVID-19. We can reframe our current embrace of remote learning and the learning of neologisms like "asynchronous" in response to the pandemic less as an imposition and, increasingly, as an expansion and new expression of hospitality. This is not only an opportunity; but also, our duty. Just like it is our duty to critique and deconstruct these new modalities in order to improve them once we have properly welcomed them to our midst. 


\section{Parting Thoughts}

A conversation about radical hospitality in universities for the 21 st century is necessary because, judging by the first two decades, we are off to a rough start. The practice of radical hospitality requires us to take a long and hard look at the most vulnerable aspects of the experience of international students and to turn that gaze toward the most vulnerable groups in higher education mobility, which, despite their vast numbers, are often invisible. The conversation about hospitality is needed because we recognize that the other's presence is indeed a disruption to our everyday life, but not nearly as significant as the disruption to theirs, especially when we talk about the growing number of displaced academics, students of refugee backgrounds, or stranded international students.

The first two decades of this century and the first seven decades of IAU's existence serve as reminders that we need universities to serve as sanctuaries and beacons and work according to principles of hospitality and solidarity because we are all one epidemic away, or one government flirting with totalitarianism away, or one economic crisis away from closures, disbandment and mass dismissals. We exercise hospitality today, not only inspired by deep empathy for the other and responding as their hostage but rather because we all are hostages to a future that is cruelly uncertain.

\section{References}

Bauman, Z. (2016). Strangers at our door. Wiley.

Derrida, J. (2005a). The future of the profession or the unconditional university (thanks to the "humanities," what could take place tomorrow). Deconstructing Derrida ,pp. 11-24. Palgrave Macmillan, New York.

Derrida, J. (2005b). The principle of hospitality. Parallax, 11(1), 6-9.

Dufourmantelle, A., \& Derrida, J. (2000). Of hospitality. Stanford University Press.

Lévinas, E. (1989). The other in Proust. In S. Hand (Ed.), The Levinas reader, pp. 160-165. Oxford: Blackwell.

Gerardo L. Blanco is Associate Professor of Higher Education and Director of the Center for International Higher Education at Boston College. His research explores the intersections of quality and internationalisation of higher education. A Fulbright Specialist, and a past Erasmus+ Teaching Fellow, his professional activities have taken place in 14 countries and 5 continents. He has taught at the University of Massachusetts Boston, the University of Connecticut, Shaanxi Normal University, and the John Paul II University of Lublin. 
Open Access This chapter is licensed under the terms of the Creative Commons Attribution 4.0 International License (http://creativecommons.org/licenses/by/4.0/), which permits use, sharing, adaptation, distribution and reproduction in any medium or format, as long as you give appropriate credit to the original author(s) and the source, provide a link to the Creative Commons license and indicate if changes were made.

The images or other third party material in this chapter are included in the chapter's Creative Commons license, unless indicated otherwise in a credit line to the material. If material is not included in the chapter's Creative Commons license and your intended use is not permitted by statutory regulation or exceeds the permitted use, you will need to obtain permission directly from the copyright holder. 